\title{
IAMJ
}

INTERNATIONAL

AYURVEDIC

MEDICAL JOURNAL

Research Article

ISSN: 2320-5091

Impact Factor: 6.719

\section{AKSHADI TAILA NASYA AND VIDDHAKARMA IN THE MANAGEMENT OF PRATH-AMAPATALAGATATIMIRA - A PILOT STUDY}

\author{
Priyanka Patil ${ }^{1}$, Nutan R Radaye ${ }^{2}$, Govind Lihinar ${ }^{3}$ \\ ${ }^{1}$ Final Year PG Student; ${ }^{2}$ HOD \& Professor; ${ }^{3}$ Lecturer \\ ${ }^{1,2}$ Department of Shalakya Tantra, YMT Ayurvedic Medical College, Kharghar, Navi Mumbai, Maharashtra, India \\ ${ }^{3}$ Department of Shalakya Tantra, APM' Ayurved Mhavidyalaya, Sion, Mumbai, Maharashtra, India
}

Corresponding Author: priyankahpatil237@gmail.com

https://doi.org/10.46607/iamj1609082021

(Published Online: August 2021)

Open Access

(C) International Ayurvedic Medical Journal, India 2021

Article Received: 30/07//2021 - Peer Reviewed: 11/08/2021 - Accepted for Publication: 14/08/2021

Check for updates

\begin{abstract}
The eye is the prime sense organ among all sense organs, thus the word Drushti indicates the function of vision. Sushruta has described 12 Drishtigat rogas in Uttartantra. The anatomical consideration of Patalas \& symptoms of the vitiated Doshas situated in these Patalas reveals that the word Timira which is described as an ocular pathology in Ayurveda is nothing but errors of refraction. Myopia, a form of refractive error where the distant vision is compromised, embraces a large section of the present-day population. In today's world, the pace of life has become fast, irregular and stressful, due to which the visual acuity gets impeded, which can be correlated with Timira described in Ayurvedic classics. Prathama Patalagata Timira is explained by all Acharyasas a Sadhya Drishtigata Roga. When vitiated Doshas reaches the Pratham Patala of the eye, the patients have blurred vision; this stage is characterized by Avyaktasdarshana (Sushruta) \& Animitta Avyakata Rupa Darshana (Vagbhata). Vagbhata has described Nasya as a treatment modality for Urdhwajatrugata Vikaras Sushruta has described Viddhakarma as a treatment modality for Timira in Sutrasthana. Akshadi Taila Nasya Yoga is explained in Ashtang Hrudaya. In the present trial, 30 patients of Prathama Patalagata Timira were selected and Nasya of Akshadi Taila was done along with Viddhakarma.
\end{abstract}

Keywords: Timira, Nasya, Akshadi Taila, Simple myopia, Viddhakarma 


\section{INTRODUCTION}

The eye is the prime sense organ among all sense organs, the word Drishti indicates the function of vision. Sushruta has described 12 Drishtigat Rogas in Uttartantra $^{[1]}$. The anatomical consideration of Patalas \& symptoms of the vitiated Doshas situated in these Patalas reveal that word Timira which is described as an ocular pathology in Ayurveda, is nothing but errors of refraction. The word Timira indicates darkness; the clinical features of Timira are related to the dominance of vitiated Dosha where the severity of the disease depends upon the number of Patalas involved. When the Dushit Dosha achieve Urdhvagamitva and reaches the first Patalas of the eye, the patient will have blurred vision. This stage is characterized by Avyaktasdarshana ${ }^{[2]}$ and Animitta Avyakta Rupadarshana by Vagbhata ${ }^{[3]}$. When the Dushit Dosha achieve Urdhvagamitva and reaches the second Patalas of the eye. It is characterized by Vihwaladarshana and Gocharavibhrama ${ }^{[4]}$ In today's world, the pace of life has become fast, irregular and stressful, due to which the visual acuity gets impeded, which can be correlated with Timira described in Ayurvedic classics. Sushrutacharya has given an algorithm of the progress of the visual disturbances in the form of Timira. Timira being Nidanarthakara Roga for Lingnasha as untreated Timira leads to Kacha which further untreated leads to Linganasha ${ }^{[5]}$ which is total blindness hence emphasis is given on prompt management of Timira. Myopia is one of the refractive errors in which parallel rays of light come to focus anterior to the light-sensitive part of the retina when accommodation is at rest ${ }^{[6]}$. Myopia has global implications on human life. Myopia is the $4^{\text {th }}$ major cause of visual loss after cataracts, glaucoma, and senile macular degeneration. As it affects young people, it can hinder education, personality development and career opportunities that interfere with the overall quality of life. Here, the importance of the classical approach in the management of eye diseases as told in Ayurveda cannot be ignored, but there is a need to re-establish the same in the modern age. Therapeutic measures mentioned in the treatment of Timira, we find that the treatment includes Snehapana, Raktamokshana, Virechana, Nasya, Anjana,
Shirobasti, Basti, Tarpana, Mukhalepa, Seka. ${ }^{[7]}$ Vagbhata has described Nasya as a treatment modality for Urdhwajatrugata Vikaras. Vagbhata had described Akshadi Taila Nasya for the treatment of Patalgata Vikaras in the Ashtanghrudaya ${ }^{[8]}$. The relevant literature and discussion suggested that Nasya with Akshadi Taila seems to be a promising modality to tackle this problem, hence it was decided to study the effect of Akshadi Taila Nasya in the Timika. Acharya Sushruta has described in Timira, Siravedha should be done at Upanasika, Apanga and Lalaat Pra$\operatorname{desh}^{[9]}$.

Spectacles are used to correct the refractive error but it neither cures nor prevents the progression of the pathology of myopia, Though Laser and surgical measures are widely used in practice for correction of myopia, they are not without complications. The cost of the surgery is also out of reach of the common man. Hence the above topic has been selected for the pilot study.

Nasya is widely practised in refractive errors \& Viddhakarma is a simple, non-invasive, cost-effective procedure.

\section{OBJECTIVES OF THE STUDY:}

1. To evaluate the efficacy of Akshadi Nasya in Pratham Patalgat Timira \& Myopia.

2. To evaluate the efficacy of Nasya \& Viddhakarma in relieving asthenopic symptoms such as headache, eyestrain, watering of the eyes.

\section{MATERIALS \& METHODS}

An open randomized clinical trial was conducted on 34 patients, diagnosed as Pratham Patalgata Timirasimple myopia.

\section{INCLUSION CRITERIA}

1) Patients were irrespective of their gender, caste, religion.

2) Patients between the age group of 18 years to 30 years

3) Patients diagnosed as Prathama Patalgata Timira (simple myopia) (<-3 diopters)

\section{EXCLUSION CRITERIA}

1) Pathological myopia, High myopia with degenerative and gross retinal changes. 
2) Myopia is associated with neighbouring structural deformities like corneal opacity.

3) Patients suffering from any of the systemic disorders.

4) Patients who have undergone any of the refractive surgeries.

5) Patients who are contraindicated for Nasya.

\section{WITHDRAWAL CRITERIA:}

Written consent was taken from each patient willing to participate, before starting the study. The patients were free to withdraw their names from the study at any time without giving any reason.

\section{GROUPING}

Group A: Nasya

Group B: Nasya followed by Viddhakarma

Akshadi Taila ${ }^{[10]}$

Akshadi Tail

Table 1: Content

\begin{tabular}{|c|c|c|c|c|c|c|c|}
\hline Drug & Latin Name & Part used & Rasa & Guna & Virya & Vipaka & Doshakarma \\
\hline Bibhitaka & $\begin{array}{l}\text { Terminalia bellirica } \mathrm{R} \\
\text { Oxb (API) }\end{array}$ & Fruit & Kashaya & $\begin{array}{l}\text { Ruksha, } \\
\text { Laghu }\end{array}$ & Ushna & Madhur & Tridoshahar \\
\hline Bhringaraja & Eclipta alba Hassk (API) & $\begin{array}{l}\text { Whole } \\
\text { plant, } \\
\text { seeds }\end{array}$ & $\begin{array}{l}\text { Katu, } \\
\text { Tikta. }\end{array}$ & $\begin{array}{l}\text { Ruksha, } \\
\text { Laghu }\end{array}$ & Ushna & Katu & Kaphavatashamak \\
\hline Asana (vijaysar) & $\begin{array}{l}\text { Pterocarpusmarsupium Roxb } \\
\text { (API) }\end{array}$ & $\begin{array}{l}\text { Trunk, } \\
\text { resin }\end{array}$ & Kashaya & $\begin{array}{l}\text { Laghu, } \\
\text { Ruksha }\end{array}$ & Sheeta & Katu & Kaphapittashamak \\
\hline Tila Taila & Sesamum indicumLinn (API) & Seeds(Oil) & Madhura & $\begin{array}{l}\text { Guru, } \\
\text { Snigdha, } \\
\text { Sukshma, } \\
\text { Vyavayi, } \\
\text { Vishada }\end{array}$ & Ushna & Madhura & Vatakaphashamaka \\
\hline
\end{tabular}

PREPARATION OF AKSHADI TAILA ${ }^{[11]}$ : Preparation of the study drug as per the description, $300 \mathrm{gm}$ Tila Taila along with 300gm of Aksha Tail is to be mixed with 1.2lit of Bhringaraj Swaras and1.2lit part of Asana Kwath and4.8 litre of water and heated till the water contents are evaporated and Siddha Tail is obtained by straining through a clean cloth and stored in a glass container.

MODE OF ADMINISTRATION: -Nasya

DOSAGE: 6 Bind $u$ per nostril ${ }^{[12]}$

DURATION: 21 days. ${ }^{[13]}$

METHOD OF NASYA KARMA:

Purva Karma: The patient was asked to lie down comfortably in a supine position on a table and $A b$ hyanga with lukewarm Tila Taila was done over the face, scalp, temporal, and neck region After completion of Abhyanga, Mrudu Swedana was done by covering the eyes.

Pradhana Karma: After Purvakarma, the patient was asked to relax and lie down on a table in the supine position and the head portion was made to extend further from the edge of the table ending at an angle. Akshadi Taila was taking Gokarna and 6 drops were administered in each nostril. Thereafter patient was instructed to inhale deeply and was advised to spit out the drug reaching the throat.

Pashchat Karma: After performing the Nasya Karma, the patient was allowed to relax in the supine position. The patient was advised to spit out the nasal secretion reaching the throat. After this procedure gargling with lukewarm water was given to the patient. After this, the patient was instructed not to take cold food or water and to avoid exposure to wind and dust.

VIDDHAKARMA: 3 sitting after each 7 days Viddhakarma points are described by Sushruta are-

1. Lalaate

2. Apang

3. Upnasika

\section{- LOCATION:}




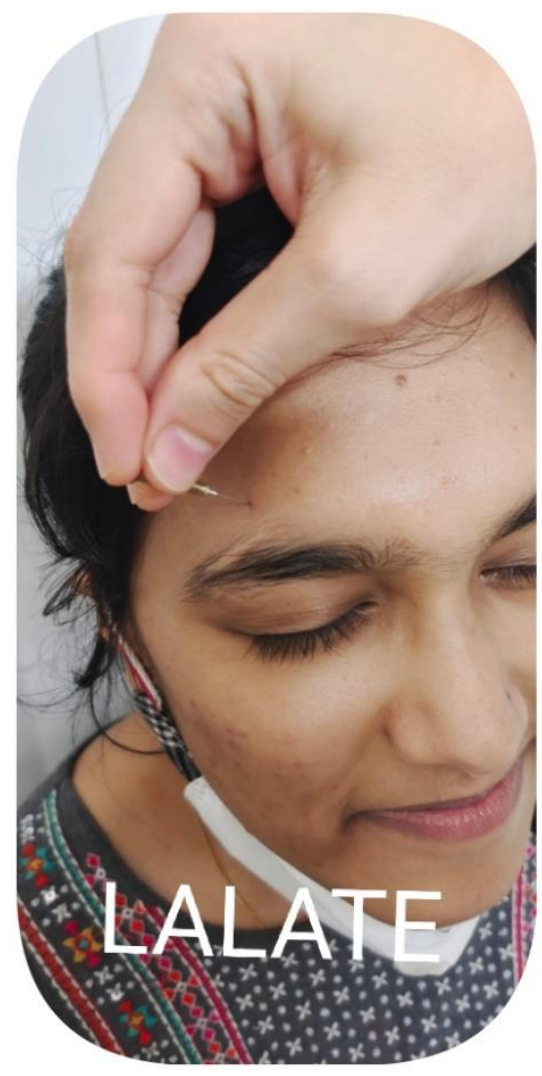

STANDARD OPERATING PROCEDURE OF VIDDHAKARMA:

Pre-procedure:

- Patients were asked to visit the hospital during OPD hours.

- Written consent was taken.

- Patients were made to lie down in a supine position with thumbs touching their respective palms and fists clenched tightly.

\section{Procedure}

- The area was cleaned with a betadine solution swab.

- With a 26 no. 0.5-inch needle, held perpendicular to the site of Viddha, a gentle prick of $1.5-2.5 \mathrm{~mm}$ deep

(Since the subcutaneous layer is vascular and is around 1.5-2.5 mm deep33) made at Upanasika, Lalaat and Apanga each on both right and left aspects of the face.

\section{Post-procedure}

- Blood oozed out from the pricked site was wiped with cotton.

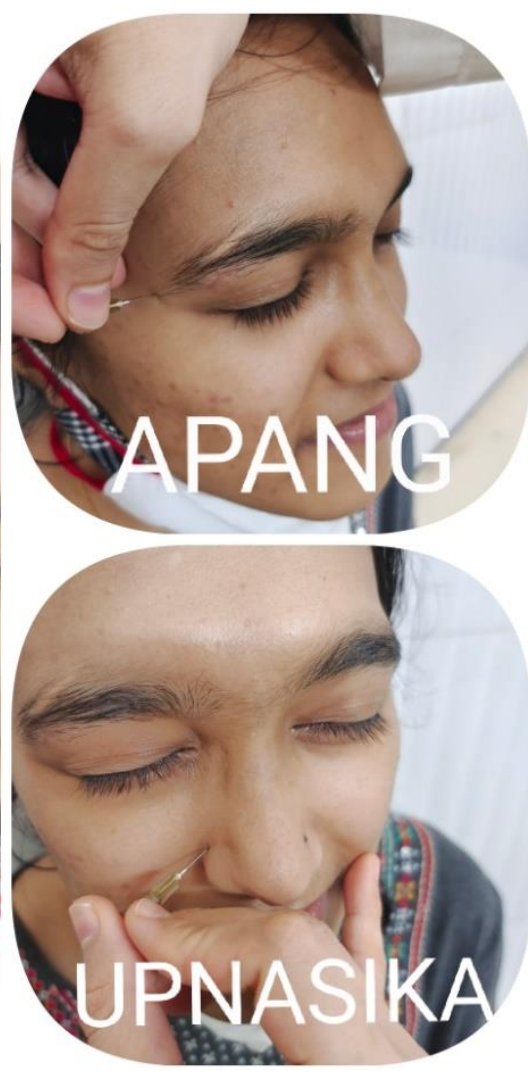

- The needle used for Viddhakarma was disposed off.

\section{CRITERIA FOR ASSESSMENT OF EFFECTS OF THE TREATMENT:}

The assessment was based on relief found in the clinical signs and symptoms of the disease. For this purpose, main clinical signs and symptoms were given suitable scores according to their severity, and assessment was done before, during and after treatment. Following symptoms were assessed according to their respective gradations.

\section{FOLLOW-UP STUDY:}

The effect of the therapies was compared before and after the treatment based on a self-formulated scoring scale to signs and symptoms in Subjective parameters.

\section{SUBJECTIVE PARAMETERS:}

1. Durastha Avyakta Darshana (indistinct distance vision)

2. Vihwala Darshana (blurred vision)

3. Dwidha Darshana (diplopia)

4. Shirobhitapa (headache) 
5. Netrayasa (eyestrain)

6. Netradaha (burning sensation)

7. Netrasrava (watering eye)

\section{OBJECTIVE PARAMETERS}

1. Visual acuity

Autorefraction

\section{ASSESSMENT ON RESPONSE}

\section{Table 2:}

Visual acuity on Snellen's

One line improvement

Assessment on response

Two-line improvement Mild

>2lineimprovement Moderate

Marked

\section{AUTOREFRACTION}

\section{Table 3}

\begin{tabular}{|l|l|}
\hline 0.0 & 0 \\
\hline-0.25 to- 0.50 & 1 \\
\hline-0.75 to- 1.00 & 2 \\
\hline-1.25 to- 1.50 & 3 \\
\hline-1.75 to- 2.00 & 4 \\
\hline-2.25 to- 2.50 & 5 \\
\hline-2.75 to- -3.00 & 6 \\
\hline
\end{tabular}

Table 4: Effect of Nasya on visual acuity in the group of 15 patients (30 eyes) of Timira-myopia

\begin{tabular}{|c|c|c|c|c|c|c|c|c|}
\hline & \multirow{2}{*}{ No. of patients } & Mean & \multicolumn{2}{|c|}{ Mean \pm SE } & \multirow[t]{2}{*}{ Percentage (\%) } & \multirow[t]{2}{*}{ SD } & \multirow[t]{2}{*}{ ' $t$ ' } & \multirow[t]{2}{*}{$P$-value } \\
\hline & & BT & AT & & & & & \\
\hline $\mathrm{RE}$ & 15 & 33.13 & 38.7 & $5.56 \pm 2.03$ & 16.80 & 7.90 & 2.73 & $<0.05$ \\
\hline LE & 15 & 36.93 & 42.0 & $5.07 \pm 2.09$ & 13.72 & 8.10 & 2.42 & $<0.05$ \\
\hline
\end{tabular}

BT-Before treatment, AT-After treatment, SE-Standard error, SD - Standard deviation, RE -Right eye, LE -left eye.

Table 5: Effect of Nasya followed by Viddhakarma on the visual acuity in the group of 15 patients (30eyes) of Timira-myopia

\begin{tabular}{|c|c|c|c|c|c|c|c|c|}
\hline & No. of patients & Mean & \multirow{2}{*}{\multicolumn{2}{|c|}{$\begin{array}{l}\text { Mean } \pm \text { SE } \\
\text { AT }\end{array}$}} & Percentage (\%) & SD & ' $t$ ' & $P$-value \\
\hline & & BT & & & & & & \\
\hline $\mathrm{RE}$ & 15 & 23.6 & 28.3 & $6.37 \pm 2.59$ & 26.98 & 10.03 & 2.46 & $<0.05$ \\
\hline LE & 15 & 29.7 & 36.63 & $6.93 \pm 2.55$ & 23.34 & 9.88 & 2.71 & $<0.05$ \\
\hline
\end{tabular}

BT-Before treatment, AT-After treatment, SE-Standard error, SD - Standard deviation, RE -Right eye, LE -left eye.

Table 6: Effect of Nasya on the dioptric power in the group of 15 patients (30eyes) of Timira-myopia

\begin{tabular}{|c|c|c|c|c|c|c|c|c|}
\hline & No. of patients & Mean & \multirow{2}{*}{\multicolumn{2}{|c|}{$\begin{array}{l}\text { Mean } \pm \text { SE } \\
\text { AT }\end{array}$}} & Percentage (\%) & SD & ' $t$ ' & $P$-value \\
\hline & & BT & & & & & & \\
\hline RE & 15 & 2.13 & 1.75 & $0.38 \pm 0.07$ & 17.97 & 0.28 & 5.28 & $<0.001$ \\
\hline LE & 15 & 1.95 & 1.63 & $0.28 \pm 0.06$ & 14.53 & 0.24 & 4.43 & $<0.001$ \\
\hline
\end{tabular}

BT-Before treatment, AT-After treatment, SE-Standard error, SD - Standard deviation, RE -Right eye, LE -left eye. 
Table 7: Effect of Nasya followed by Viddhakarma on the dioptric power in the group of 15patients (30 eyes) of Timira-myopia

\begin{tabular}{|c|c|c|c|c|c|c|c|c|}
\hline & \multirow[t]{2}{*}{ No. of patients } & \multirow{2}{*}{$\begin{array}{l}\text { Mean } \\
\text { BT }\end{array}$} & \multirow{2}{*}{\multicolumn{2}{|c|}{$\begin{array}{l}\text { Mean } \pm \text { SE } \\
\text { AT }\end{array}$}} & \multirow[t]{2}{*}{ Percentage (\%) } & \multirow[t]{2}{*}{ SD } & \multirow[t]{2}{*}{ ' $t$ ' } & \multirow[t]{2}{*}{$P$-value } \\
\hline & & & & & & & & \\
\hline $\mathrm{RE}$ & 15 & 02.48 & 01.88 & $0.6 \pm 1.27$ & 24.16 & 4.92 & 02.22 & $<0.05$ \\
\hline LE & 15 & 02.18 & 01.62 & $0.57 \pm 0.14$ & 25.95 & 5.09 & 02.25 & $<0.05$ \\
\hline
\end{tabular}

BT-Before treatment, AT-After treatment, SE-Standard error, SD - Standard deviation, RE -Right eye, LE -left eye.

Table 8: Overall effects of therapies on 30 patients (60 eyes) of Timira-myopia

\begin{tabular}{|l|l|l|l|l|l|}
\hline Overall effect & Group A & & Group B \\
\hline & No. of eyes & Percentage (\%) & No. of eyes & Percentage (\%) \\
\hline Cured & 0 & 0 & 0 & 0 \\
\hline Marked improvement & 0 & 0 & 0 & 0 \\
\hline Moderate improvement & 06 & 20 & 10 & 33.33 \\
\hline Mild improvement & 20 & 66.67 & 18 & 60 \\
\hline Unchanged & 04 & 13.33 & 02 & 06.67 \\
\hline
\end{tabular}

\section{DISCUSSION}

Apart from the clinical features of the Prathama Patalgata Timira can be correlated with myopia, which is the most important refractive error. Avyakta Darshana or blurring of vision for distance is a symptom produced due to affliction of the first Patala, which occurs in the myopia of low degree. The cardinal symptom of myopia, that is, difficulty in distant vision is seen when the vitiated Doshas are lodged in the upper part of the Drishti. The Vihwala Darshana symptom is produced due to the affliction of the second Patala that occurs due to progressive myopia, which results in vitreous degeneration, retinal degeneration, and ultimately retinal detachment in the advanced stage.

\section{MODE OF ACTION OF DRUGS}

In the Akshadi Taila, TilaTaila, which is used as the medium or vehicle, clears all the minute channels (Srotas) by virtue of its Gunas like Vyavayi, Vikashi, and Sara. ${ }^{[13]}$ Almost all the Ayurvedic scholars have described it as Vata-Kaphahara and Pitta Vardhaka in general, but they further clarify that it destroys all diseases due to Samyoga (Sneha Pravicharana) and Samskara (processing with the drugs that cause the addition of new properties). Taila does not have Sanskaranuvartana Guna and so loses its inherent property (Ushna) during its processing with Sheeta Virya drugs (e.g., Vijaysaar), hence, it is processed with Pitta Shamaka drugs. Before Nasya, Abhyanga is specifically done in Murdha Pradesha. It increases the secretion of the vitiated Shleshma through the channels. Therefore, due to the Ushna Guna of Swedana, the Kapha Pitta Doshas get pacified. When lukewarm oil enters the nasal cavity, a network of Srotamsi carries the Taila toward the desired sites and cleanses the channel. By the effect of Tridosha Shamaka, the Ama is digested at the cellular level and pacifies the vitiated Vata and Kapha Dosha. Due to Ama Pachana and Vata Kapha Shamana, Avarana and Sanga of Vata Kapha Dosha are removed. Therefore, after breaking Avarana and Sanga by Nasya has been carried out in the Timira - myopia patients in the present study. According to Samanya Samprapti of Netraroga Vikara with the help of Siras vitiated Doshas are carried out in an upward direction (Urdhwajatrugat) and causes localized Dosha Dushti which ultimately leads to Timira. Bloodletting Caused by Viddhakarma breaks the Avarana and Sanga of Vata-Kapha Dosha \& channelizes the Doshas in Samyak state which causes the Samprapti bhanga of Timira. Thus, the overall effect of the Nasya \& Viddhakarma is Tridoshashamaka, and hence, it disintegrates the pathogenesis of the disease Timira, which is Tridoshaja in its manifestation. 


\section{CONCLUSION}

Nasya followed by Viddhakarma in group B provided better results in chief complaints like Durastha Avyakta Darshana, Vihwala Darshana, Netrayasa, and Shirobhitapa. In few patients, even if no change in clinical refraction was observed, still the overall clarity of vision was found to be improved and asthenopic symptoms like Netrayasa, Netrasrava, Netradaha, and the like were remarkably reduced.

Our study showed that both Nasya and Viddhakarma can improve mild and/or moderate myopia of patients. Viddhakarma along with Nasya seems to be more effective than only Nasya in treating myopia however at the moment we do not have conclusive explanations concerning the underlying mechanisms of needle and thermal stimulation on myopia from a neurophysiological perspective.

\section{REFERENCES}

1. Sushruta. Sushruta Samhita, Uttara Tantra. G.D. Singhaland K.R. Sharma, IMS: BHU, Varanasi, Chaukhamba Vidya Bhavan, Varanasi.

2. Sushruta. Sushruta Samhita with Nibandhasamgraha Vyakhya, Dalhana: Yadavji Trikamji Acharya, Chaukhamba Sanskrit Series, Varanasi

3. Udayashankar Bhat. A Clinical Study on the Effect of Chakshushya Drugs, 1990. [Thesis-Gujarat Ay-urved University]

4. Vagbhata. Ashtanga Hridayam Uttaratantra with Bhagirathi Tippani (TaradattaPanna) Edition II, Chaukhamba Sanskrit series office, Varanasi,1980

5. Vagbhata. Ashtanga SamgrahawithIndu Commentary, Ed. Athavale A.D., Atreya Prakashana, Pune, 1980

6. A.K. Khurana Comprehensive Ophthalmology, New Age International Publishers, Edition 5, 2012, Chapter No-3, Page No 32-33

7. Sushruta. Sushruta Samhita, Uttara Tantra. G.D. Singhaland K.R. Sharma, IMS: BHU, Varanasi, Chaukhamba Vidya Bhavan, Varanasi

8. Ganesh Garde, Sartha Vagbhata, Chaukhamba Surbharati PrakashanVaranasi, edition 2009, page no.391 A.HU.13/46.

9. Dr Ghanekar G.B., Sushrut Samhita: Sharirsthanam with Ayurveda rahasyadipika Hindi commentary, New Delhi, Meharchand Lachhmandas Publications, 2001, chapter 8, shlok 29, pg. no. 223

10. Bramhanand Tripathi, Sharangadhara Samhita
Chaukhamba Surbharati PrakashanVaranasi, 2013, Page No.144, Sha.9/1.

11. Drushtarth Ashtang Sangrah, Pratham Khand, Translated by Vd. PadmakarAthavale, Drushtarthmala Prakashan, Third Edition Reprint 1998, Ashatang Sangrah Sustrasthan, Adhyay 29, VerseNo.12, PageNo.235

12. Sushruta, Sushrut Samhita, Translated by Narayanram, Krishnadas Academy, Varanasi, Chowkhamba press, Varanasi, EditionReprint199, Sushrut Chikitsa Adhyay 40, VerseNo.42, PageNo.556

13. Sushruta Samhita, Yadavaji T. Nibandhasarsangraha Vyakhya by Dalhana, Sutra Sthana, Varanasi, Chaukhmba Sannskrit Series, 2008, 45/122, Page No 205.

\section{Source of Support: Nil Conflict of Interest: None Declared}

How to cite this URL: Priyanka Patil et al: Akshadi Taila Nasya And Viddhakarma In The Management of PrathAmapatalagatatimira - $\mathcal{A}$ Pilot Study. International Ayurvedic Medical Journal \{online\} 2021 \{cited August 2021\} Available from:

http://www.iamj.in/posts/images/upload/1704_1710.pdf 